\title{
Pemberdayaan Ekonomi Masyarakat Berbasis Masjid di Tengah Pandemi Covid-19
}

\author{
Muhammad Muhib Alwi \\ Institut Agama Islam Negeri Jember \\ muhibalwiafifa@gmail.com
}

\begin{abstract}
So far, masjids (mosques) have only been used as places of mahdhoh ibadah (the worship of Allah). However, during the time of the Prophet Muhammad, masjids were functioned as the center of government, economic, education, defense and security center, and others. The view that considers the masjid only as a place of mahdhoh ibadah (worship) causes the economic development of the masjid and the surrounding community to be less developed, so that the condition of the masjid cannot be independent, let alone to help the welfare of the surrounding community. Since the time of the Prophet, the people around the masjid have been able to take advantage of the masjid-based economic system, namely through Baitul Maal Wat Tamwil (BMT). This institution has become one of the economic institutions that is able to guarantee the economic independence of the masjid and at the same time help empower the economy of the people around it. Especially at this time, the economic condition of the community is in sharp decline due to the Covid-19 pandemic. It takes togetherness from all masjids to help each other and strengthen the community's economy.
\end{abstract}

Keywords: Empowerment, Economy, Society, Masjid, Covid-19 Pandemic.

\begin{abstract}
Abstrak
Masjid selama ini hanya dijadikan sebagai tempat ibadah mahdhoh, padahal pada masa Rasulullah SAW masjid difungsikan sebagai pusat pemerintahan, pusat ekonomi, pusat pendidikan, pertahanan, dan keamanan, dan lain-lain. Pandangan yang menganggap masjid hanya sebagai tempat ibadah mahdhoh menyebabkan kurang berkembangnya ekonomi masjid dan masyarakat disekitarnya, sehingga kondisi masjid tidak bisa mandiri apalagi membantu kesejahteraan masyarakat di sekitarnya. Sejak jaman Nabi masyarakat di sekitar masjid sudah dapat mengambil manfaat dari sistem ekonomi yang berbasis masjid, yaitu melalui Baitul Maal Wat Tamwil (BMT) lembaga ini menjadi salah satu lembaga ekonomi yang mampu menjamin kemandirian ekonomi masjid dan sekaligus membantu pemberdayaan ekonomi masyrakat di sekitarnya. Terutama saat ini, kondisi ekonomi masyarakat sedang menurun tajam karena pandemi covid-19. Butuh kebersamaan dari seluruh jamaah masjid untuk saling membantu dan menguatkan ekonomi masyarakat.
\end{abstract}

Kata Kunci: Pemberdayaan, Ekonomi, Masyarakat, Masjid, Pandemi Covid-19. 


\section{Pendahuluan}

Sejarah Islam membuktikan betapa masjid memiliki fungsi sentral dalam kehidupan kaum muslimin, sebagai contoh adalah keberadaan Masjid Nabawi di Madinah pada masa Rasulullah SAW. Termasuk di Indonesia Islam disebarkan dan dipelajari melalui masjid, dimana masjid memainkan peran penting dalam kehidupan masyarakat. Masjid tidak saja sebagai tempat melakukan aktivitas ibadah kaum muslimin, melainkan sudah menjadi lembaga pendidikan secara umum. Melalui masjid pendidikan dan pembinaan ummat dilakukan secara intensif sehingga mampu melahirkan ulama-ulama besar.

Ikon masjid sebagai pusat ibadah sekaligus aktivitas sosial umat Islam juga seringkali dinodai oleh berbagai fenomena "meminta-minta" atas nama kegiatan masjid. Di beberapa daerah saat ini seringkali dijumpai mobil keliling dengan suara keras menggunakan microphone meminta-minta sumbangan untuk pembangunan sebuah masjid. Tentu saja hal ini bukan sebuah kesalahan, tetapi banyak suara miring mengenai hal ini. Selain menggunakan mobil yang keliling, seringkali ke wilayah-wilayah yang jauh dari daerah masjid itu dibangun. Fenomena memintaminta ini juga dapat disaksikan di beberapa masjid yang dibangun di pinggirpinggir jalan dengan pengeras suara meminta sumbangan dan memasang "polisi tidur" agar pengendara mobil/sepeda motor memelankan laju kendaraan dan melemparkan sumbangannya.

Permasalahan yang dihadapi masjid tidak berhenti sampai disitu. Setelah masjid terbangun tidak sedikit masjid yang dibangun lebih megah daripada rumahrumah yang menempel di samping kanan dan kirinya, masalah jamaah yang mengisi masjid pun menjadi masalah ketika masjid yang dibangun dengan cukup megah ternyata tidak sesemarak para pengisi aktifitas kemasjidannya. Permasalahan pengelolaan masjid menjadi permasalahan yang harus mendapat perhatian serius mengingat masjid adalah lembaga keagamaan yang memiliki fungsi sosial cukup signifikan dalam sebuah masyarakat. Pengelolaan masjid yang professional dan pemberdayaan masjid agar dapat mandiri dalam pengelolaannya tanpa harus keluar dari nilai-nilai kemasjidan merupakan hal yang dapat menarik jamaah. Tertama saat ini, kehadiran masjid sebagai lembaga keagaam dan sosial menjadi sangat penting. Masyarakat (jamaah masjid) banyak yang terimbas pandemi covid-19, dimana ekonomi merosot tajam dan kebutuhan pangan menjadi satu krisis tersendiri. Bagaimana pengelolaan ekonomi berbasis masjid untuk saling membantu menjadi sebuah fenomena yang tidak terelakkan lagi.

Ketika masyarakat yang hidup pas-pasan secara ekonomi selalu diminta menyumbang setiapkali ada kegiatan kemasjidan akan merasa terbebani ketika mengetahui ada acara yang akan dilangsungkan oleh takmir masjid. Hal demikian tentu saja berimbas pada frekuensi kegiatan yang ada di masjid, bagi masyarakat tersebut mungkin akan merasa tenang ketika masjid tidak banyak 
menyelenggarakan kegiatan, sehingga fungsi masjid tidak banyak memberikan imbas positif bagi masyarakat. Kondisi demikian akan berbeda dengan kondisi masjid yang sudah melakukan pemberdayaan secara ekonomi. Ekonomi kemasjidan yang diselenggarakan oleh masjid-masjid yang telah ditangani secara professional justru akan membuat aktifitas kemasjidan menjadi semarak tanpa harus memberatkan masyarakat dan masyarakat dapat beribadah dengan tenang dan menjalankan aktifitas keagamaan dengan semarak sesuai dengan nilai-nilai keislaman. Saat ini, pengelola masjid dituntut untuk mengedepankan keperdulian sesama dan menjadi play maker dalam pengelolaan sumbangan dari masyarakat, oleh masyarakat, dan untuk masyarakat. Sumbangan tidak hanya digunakan untuk kegiatan ketakmiran masjid namun juga untuk memberikan penghidpan bagi jamaahnya.

Masjid bukan hanya sebatas pusat kegiatan ibadah bagi para jamaahnya, tetapi masjid diharapkan dapat menjadi pusat aktiftas sosial dan ekonomi bagi para jamaahnya. Konsep pemberdayaan menjadi penting karena dapat memberikan perspektif positif terhadap pemanfaatan sumber daya masjid yang ada. Komunitas yang diberdayakan tidak dipandang sebagai komunitas yang menjadi objek pasif penerima pelayanan, melainkan sebuah komunitas yang memiliki beragam potensi dan kemampuan yang dapat diberdayakan. Kegiatan pemberdayaan komunitas dalam hal ini umat Islam (mustahik) dapat dilakukan melalui pendampingan dengan memberikan motivasi, meningkatkan kesadaran, membina aspek pengetahuan dan sikap meningkatkan kemampuan, memobilisasi sumber produktif dan mengembangkan jaringan. Sehingga terbangun sinergi yang kuat antara potensipotensi yang ada.

Pengembangan sumber daya ekonomi jamaah dalam membangun masjid dan memberdayakan jamaah, merupakan sebuah cita-cita besar tentang revitalisasi fungsi masjid sebagai wadah pemberdayaan umat. Cita-cita besar ini merupakan sesuatu yang sangat historis dan sesuai dengan konteksnya karena dalam Islam idealnya masjid adalah pilar utama dan terpenting bagi pembentukan masyarakat Islam. Karena masyarakat muslim tidak akan terbentuk secara kokoh dan rapi kecuali dengan adanya komitmen terhadap sistem, akidah dan tatanan Islam. Hal ini tidak akan dapat dimunculkan kecuali di masjid.

Melihat gejala yang sedang berkembang di tengah masyarakat akibat pandemic covid-19 diperlukan paradigma baru dalam melihat pemberdayaan ekonomi umat ini. Mereka harus diposisikan sebagai subjek dalam pemberdayaan karena mereka merupakan bagian inklusif dan sentral dalam pembangunan ekonomi makro, perlu dilakukan pola pembangunan kemitraan baik antar masyarakat, masyarakat-pemerintah, swasta-NGO yang merupakan modal sosial (social capital) terbesar dalam membangun masyarakat. Modal sosial ini menjadi jalan tengah untuk memecah sistem kapitalis yang sangat mengedepankan individu. 
Pemerintah-masyarakat dan pemangku kepentingan (stake holder) lainnya perlu bekerja sama dengan azas kesetaraan demi kepentingan kolektif untuk mendapatkan pemenuhan hak masyarakat. Keberadaan Lembaga Amil Zakat, Infaq, dan Shodaqoh (LAGZIS) di masjid Al-Falah Perumahan Tegal Besar Permai 1 menjadi modal sosial yang kuat untuk menstimulasi kesadaran masyarakat dalam membantu sesama dalam situasi yang sulit saat itu. Lembaga ini, bisa memerankan diri sebagai pengumpul dan penyalur zakat, infaq, dan shodaqoh yang dikumpulkan dari mayarakat. Keperdulian masyarakat yang begitu besar harus diakomodir dalam satu kekuatan kelembagaan yang professional dan akuntabel.

Terdapat dua cara transfer sumberdaya ekonomi umat: Pertama, secara komersil yang terjadi melalui aktivitas ekonomi. Kedua, secara sosial terjadi dalam bentuk bantuan seperti zakat, infaq dan shadaqah. Adanya dua transfer sumber daya ekonomi ini merupakan potensi umat, karena tidak semua orang mampu melakukan proses dan aktivitas ekonomi ${ }^{1}$. Bagi yang sehat, kuat jasmani dan memiliki kesempatan, ia dapat memperoleh sumber kehidupannya dari aktivitas ekonomi. Tapi, bagi sebagaian lain yang tidak mampu, Islam melindungi dengan social economic security insurance dalam bentuk zakat, infaq dan shodaqoh. Tentunya, penyerahan zakat, infaq, dan shodaqoh ini harus diatur dan didistribusikan serta dimanfaatkan seproporsional mungkin. Muncul harapan yang dilontarkan dalam berbagai seminar tentang ekonomi Islam berbasis masjid. Bagi pakar ekonomi Islam, Syafi'i Antonio, hal ini menjadi harapan besar pengembangan ekonomi berbasis masjid dalam bentuk mengembangkan potensi ekonomi masjid yang telah ada karena selama ini banyak potensi yang terabaikan sehingga tidak mampu mewadahi potensi ekonomi masyarakat tersebut.

Kesadaran untuk mengelola secara professional baru terbangun akhir-akhir ini. Diantaranya adalah, gerakan membantu sesama yang dikelola oleh LAGZIS Masjid Al-Falah Perumahan Tegal Besar Permai 1 yang setiap hari jumat mengumpulkan sumbangan dari masyarakat untuk kemudian disalurkan kepada yang membutuhkan baik masyarakat perumahan maupun di luar perumahan. Gerakan bersama yang diikuti oleh seluruh jamaah (Bapak-bapak dan Ibu-ibu) untuk mengmpulkan sumbangan berupa uang dan sembako dan kemudian dibelanjakan sembako untuk didistribusikan kepada masyarakat menjadi suatu gerakan yang menarik. Ada pelaporan jumlah uang dan barang (sembako) yang diterima pada setiap jumat sore dan bisa diakses secara langsung oleh masyarakat membangun kepercayaan tersendiri untuk terus menyalurkan bantuannya.

${ }^{1}$ Abdul Hasan Sadeq, 1998, Economic Development in Islam, Istambul, Turki: Al-Faiz Press. 


\section{Pembahasan}

\section{Masjid dan Identitas Sosial Masyarakat Islam}

Ketika nabi Muhammad berhijrah dari Mekkah menuju Madinah, saat tiba dan diterima oleh masyarakat Madinah, yang pertama kali beliau cari adalah tempat untuk mendirikan masjid. Dalam memilih lokasi masjid bukan beliau yang menentukan, melainkan onta yang dibiarkan untuk memutuskan dimana tempat akan didirikan masjid. Onta tersebut merebahkan diri, berlutut di tempat penjemuran kurma milik Sahl dan Suhail bin 'Amr, kemudian tempat itu dibeli oleh nabi sebagai tempat untuk membangun masjid yang saat ini dikenal dengan Masjid Nabawi. ${ }^{2}$

Dalam pragmen ini ada dua pertanyaan yang cukup menarik untuk kita pertanyakan, pertama, kenapa masjid yang pertama kali beliau bangun, kenapa bukan istana ?3 , kedua, mengapa onta yang menentukan tempat bukan beliau? Jawaban pertama; istana merupakan simbol dari birokrasi keduniaan yang sekuler dan profan sedangkan masjid merupakan simbol transeden keakhiratan yang religius dan sakral. Isyarat yang dinyatakan dalam pembangunan masjid ini menjadi sebuah simbol arah pembangunan dan kekuasaan dalam Islam. Oleh karena itu dalam masyarakat Islam, masjid memiliki posisi strategis dalam memaknai religiusitas masyarakatnya. Terlebih pada fase awal kekuasaan Islam ini, masjid memiliki fungsi yang cukup luas (multifungsi). Tidak hanya sebagai tempat pembinaan spiritual melalui kegiatan ibadah ritus-personal, tapi juga sentral kegiatan publik, kebudayaan dan pusat pemerintahan Islam saat itu. ${ }^{4}$

Kondisi ini menyiratkan kepada kita bahwa masjid menjadi tonggak dan pijakan awal transformasi sosial masyarakat Islam. Masjid adalah bagian dari agen perubahan. Berbagai perubahan sosial di Madinah tidak terlepaskan dari keberadaan masjid yang dibangun Nabi di madinah saat itu. Kehidupan masjid saat itu mengajarkan sikap egaliter, disiplin, kebersamaan dan kesatuan visi dunia-akhirat. Penguatan mentalitas masyarakat melalui masjid dilakukan bersamaan dalam membangunan tatanan dan pranata sosial di Madinah.

Kedua, secara historis tidak ada informasi yang menyampaikan kenapa Nabi memilih onta untuk menentukan tempat didirikannya masjid. Melihat sikap Nabi yang selalu mengutamakan kebersamaan dalam rangka penyatuan muhajirin dan anshar, beliau tidak memutuskan sendiri walau dipersilahkan oleh kaum muhajirin dan anshar. Beliau menyerahkan kepada onta sebagai sikap pengambilan keputusan

${ }^{2}$ Haekal, Sejarah Hidup Muhammad, terj. : Ali Audah, (Jakarta : Tirtamas, 1982), Cet. VIII, h. 214

${ }^{3}$ Pernyataan dalam pertanyaan pertama ini pernah disampaikan oleh Kuntowijoyo yang penulis kutip dari makalah Imam Sofyan Abbas yang mengutip tanya-jawab Kuntowijoyo dalam tulisannya berjudul "Mesjid Dan Perubahan Sosial: Eksistensi, Partisipasi, Dan Proyeksi"

4 Badri Yatim, Sejarah Peradaban Islam, Dirasah Islamiah II, (Jakarta : PT. Raja Grafindo Persada, 2001), Cet. XII, h. 26 
menggambarkan bahwa egosentris sosial dalam membangun masjid harus dilebur. Dalam menentukan masjid tidak ada ego Muhammad, tidak ada ego muhajirin dan tidak ada ego anshor. Pada saat itu onta lah yang terpilih sebagai apparatus pengambilan keputusan yang paling netral. Hal ini menjelaskan bahwa urgensi pembangunan masjid selain untuk tempat kegiatan spiritual, juga sebagai sarana penting untuk mempersatukan kaum muslimin dan mempertalikan jiwa mereka.

Masjid pada zaman Nabi Muhammad merupakan sebuah ruangan terbuka yang luas, keempat temboknya dibuat daripada batu bata dan tanah. Atapnya sebagian terdiri dari daun kurma dan yang sebagian lagi dibiarkan terbuka, dengan salah satu bagian lagi digunakan tempat orang-orang fakir miskin yang tidak memiliki tempat tinggal. Di dekat masjid ini pula Nabi Muhammad tinggal.

Masjid yang multifungsi sebagai pusat kegiatan pemerintahan, kegiatan pendidikan, kegiatan keagamaan dan kegiatan sosial, memiliki makna penggabungan etos spiritualitas dalam kegiatan kemasyarakatan. Hal ini terjadi karena kepemimpinan tunggal yang memiliki otoritas spiritual dan temporal (duniawi) yang berdasarkan kenabian dan bersumberkan wahyu Ilahi. $^{5}$ Keberlangsungan kepemimpinan setelah wafatnya Nabi Muhammad tidak ditentukan oleh Nabi dan tidak ada satu teks pun dalam al-Qur'an dan al-Hadist yang secara langsung mengatur tata cara pergantian kepemimpinan setelah Nabi. Menariknya adalah terpilihnya Abu Bakar sebagai Khalifah karena Nabi Muhammad pernah memilih beliau sebagai imam shalat Jum'at. Analogi antara imam shalat di masjid dengan kepala Negara yang mengatur urusan politik masyarakat adalah pentingya kepala umat bukan berada dalam kompetensi dan kekuasaan yang diberikan, akan tetapi dalam kedudukannya sebagai representasi syari'at Islam pengganti tugas Nabi Muhammad selain kenabian. ${ }^{6}$

Pada fase awal Islam, terlihat jelas masjid memiliki peran sentral sebagai pusat gerak transformasi sosial. Masjid dalam hal ini tidak hanya menjadi sebuah simbol keagamaan, ia telah menjadi identitas sosial masyarakat madinah saat itu. Kehidupan sosial, politik, ekonomi dan spiritual bermuara dan bermulai dari masjid.

\section{Fungsi dan Peran Masjid Saat Ini}

Menurut hemat penulis setidaknya terdapat 5 fungsi masjid sebagaimana digambarkan pada masa awal Islam yang dapat dikembangkan saat ini, yaitu :

1. Masjid sebagai Bait Allah, artinya masjid adalah rumah ibadah kepada Allah yang merupakan inti dari kegiatan ta'mir masjid. Fungsi ini merupakan fungsi yang sudah tentu berjalan dibarisan terdepan dalam aktivitas yang dilakukan di

${ }^{5}$ Munawir Sadjali, Islam dan Tata Negara Ajaran Sejarah dan Pemikiran, (Jakarta : UI Press, 1993), hal. 21

${ }^{6}$ Marsel A. Boisard, Humanisme dalam Islam, (Jakarta : Bulan Bintang, 1980), hal. 174 
dalam masjid.

2. Masjid sebagai Bail al-Ta'lim, artinya masjid merupakan tempat penyelenggaraan pendidikan keagamaan, pusat dakwah dan sebagai tempat transformasi pemahaman keagamaan baik itu berupa pengajian, pengkajian, dan pendidikan formal yang dilakukan oleh masjid seperti pendirian Majlis Ta'lim, TPQ dan Madrasah Diniyah.

3. Masjid sebagai Bait al-Maal, yaitu masjid menjadi pusat pelaksanaan kegiatan sosial keagamaan terutama dalam peranan mengorganisir terlaksananya ibadah maliyah seperti zakat, infaq, dan shodaqoh bagi kepentingan masyarakat di sekitar masjid yang berasal dari lingkungan masjid itu sendiri.

4. Masjid sebagai Bait al-Ta'min, artinya masjid memiliki kemampuan dalam memberikan jaminan sosial bagi jama'ahnya. Pada masyarakat awal Islam, nabi Muhammad memberikan tempat khusus bagi kaum suffah dan menjamin kehidupan mereka melalui peran masyarakat yang aktif di masjid.

5. Masjid sebagai Bait Al-Tamwil, artinya masjid memiliki kemampuan untuk menghasilkan dana dari kegiatan usaha yang dilakukannya. Sehingga masjid dapat berkembang dan secara mandiri memenuhi kebutuhan keuangannya (idaroh al-maliyah).

\section{Manajemen Keuangan dan Kemandirian Ekonomi Masjid}

Masjid sebagai properti publik membutuhkan pengelolaan (manajemen) dalam rangka pemeliharaan dan pelaksanaan fungsinya bagi masyarakat. Semakin luas fungsi masjid bagi masyarakat, maka semakin dibutuhkan sumber daya manajerial yang tinggi.

Manajemen keuangan masjid yang dimaksud adalah aktivitas atau kegiatan untuk mengatur kegunaan sumber daya bagi tercapainya tujuan yang telah ditetapkan, dan proses yang sistematis sebagai alat untuk mencapai sasaran dan tujuan dengan menjalankan fungsi sesuai ketentuan yang telah ditetapkan dengan melibatkan orang lain secara efektif dan efesien yang terdiri dari tindakan-tindakan perencanaan, pengorganisasian, pengaturan, penyusunan, penggerakan, pengendalian, pengawasan dan lain-lain sehingga apa yang direncanakan dapat berjalan dengan baik dan maksimal menurut usaha dan potensi yang ada.

Artinya, aktivitas manajerial akan bergantung kepada tujuan, sistem, struktur dan sumber daya yang dimililiki. Kepemimpinan, pengawasan dan pengendalian dalam organisasi kemasyarakatan akan mengikuti struktur sosial dalam masyarakat tersebut. Sementara perencanaan merupakan gambaran dari usaha pencapaian tujuan yang ingin diraih dalam organisasi. Penggerakkan dan pengaturan merupakan cara yang dipilih untuk melaksanakan rencana.

Kegiatan organisasi kepengurusan masjid meliputi imarah (kegiatan memakmurkan masjid), ri'ayah (pemeliharaan), dan idarah (administrasi). 
Manajemen administrasi masjid (idarah masjid) pada garis besar dibagi menjadi dua bidang yaitu $:^{7}$

a. Idarah Binâil Mâdiy ( Physical Management), yaitu manajemen secara fisik yang meliputi kepengurusan masjid, pengaturan pembangunan fisik masjid; pemeliharaan, kebersihan, ketertiban dan keindahan masjid (termasuk taman di lingkungan masjid); pemeliharaan tata tertib dan keamanan masjid; pengaturan keuangan serta administrasi masjid.

b. Idarah Binâil Rûhiy ( Functional Management ), yaitu pengaturan tentang pelaksanaan fungsi masjid sebagai ruang pembinaan spiritual, pendidikan dan kemasyarakatan.

Manajemen masjid pada kedua bidang utama ini membutuhkan salah satu unsur penting dalam manajemen, yaitu unsur finansial (money) ${ }^{8}$. Karena masjid merupakan milik publik dan dikelola secara swadaya, maka sumber daya finansialnya tentu akan banyak bergantung pada upaya ekonomi dan adanya partisipasi masyarakat dimana masjid itu didirikan.

Masjid sebetulnya memiliki potensi untuk dapat mandiri secara ekonomi hal ini disebabkan masjid memiliki modal ekonomi sosial (non-finansial capital) yang cukup baik, yaitu modal institusional dan modal sosial yang tinggi.

Modal sosial adalah wujud partisipasi masyarakat terhadap persoalanpersoalan yang dihadapi bersama yang digerakkan oleh adanya trust dan disokong oleh struktur sosial. Dalam konteks manajemen keuangan masjid, modal sosial menjadi penting terutama keterkaitan dengan partisipasi dan tanggung jawab masyarakat dalam rangka menghidupkan fungsi masjid bagi masyarakat itu sendiri.

Salah satu modal sosial yang terbentuk dalam rangka kerjasama antar anggota masyarakat adalah sikap kedermawanan (Philanthropy) atau sikap partisipatif dalam hal materi dan finansial. Sikap kedermawanan dapat tumbuh didorong oleh rasa kepercayaan terhadap individu, tatanan dan struktur sosial atau juga disebabkan adanya aspek teologis yang memberikan dorongan normatif (doktrin) atas perilaku individu dan dijalankan bersama-sama oleh sebuah komunitas masyarakat untuk mencapai tujuan yang sama. Modal sosial ini jika dikelola dengan baik, akan menjadi sumberdaya ekonomi yang bisa menguatkan masyarakat dalam kondisi sulit.

${ }^{7}$ Moh. E. Ayub dkk, Manajemen Masjid, Petunjuk Praktis Bagi Para Pengurus, (Jakarta : Gema Insani Press, 1996), Cet. I, h. 33

${ }^{8}$ Unsur-unsur manajemen terdiri dari enam macam : man, money, material, machine, method, market. Lihat : Hamzah Yakub, Menuju Keberhasilan dan Kepemimpinan, (Bandung : Diponegoro, 1981), Cet. I, h. 31 


\section{LAGZIS Masjd Al Falah}

LAGZIS masjid Al Falah Perumahan Tegal Besar Permai 1 Jember secara opresional adalah LAGZIS yang proses pendiriannya dibidani dari, oleh, dan untuk takmir masjid. Takmir masjid mendirikan LAGZIS adalah untuk memberikan contoh pengamalan syariah di bidang mu'amalah sekaligus untuk pemberdayaan ekonomi jama'ah masjid. Lembaga ini sudah didirikan sejak dua tahun yang lalu, namun kurang begitu aktif. Namun lembaga ini menjadi hidup dan aktif saat pandemi Covid-19 karena kesadaran dari jamaah dan takmir masjid untuk memberikan bantuan kepada masyarakat terdampak Covid-19.

LAGZIS yang didirikan di masjid Al Falah Perumahan Tegal Besar Permai 1 Jember ini adalah lembaga yang memberikan dukungan terhadap peningkatan kualitas ekonomi jamaah dan masyarakat di perumahan dan sekitarnya dengan berlandaskan sistem syariah. Lembaga ini terdiri dari dua bagian yang disebut dengan Baitul Maal dan Baitul Tamwil. Baitul Maal adalah lembaga yang kegiatannya menerima dan menyalurkan zakat, infaq, dan shodaqoh. Sedangkan Baitul Tamwil mengembangkan usaha produktif dan investasi dalam meningkatkan kualitas usaha ekonomi jamaah dan masyarakat secara umum diantaranya dengan cara memotivasi kegiatan menabung dan pembiayaan usaha ekonomi. Sedangkan apabila dilihat dari setatus badan hukumnya, LAGZIS masjid Al Falah merupakan organisasi keuangan dan perekonomian dalam bentuk Amil Zakat (pengumpul dan penyalur zakat/ shodaqoh) dan Kelompok Simpan Pinjam (KSP) atau Kelompok Swadaya Masyarakat (KSM).

Dari uraian diatas dapat disimpulkan bahwa LAGZIS masjid Al Falah adalah lembaga keuangan yang dalam operasionalisasnya menganut sistem syariah dan fungsi utama yang diharapakan akan dapat membantu meningkatkan perekonomian masyarakat bawah terutama di tengah kondisi pandemi Covid-19 saat ini, karena LAGZIS Masjid Al Falah mempunyai peranan sebagai pengumpul dana bisnis maupun dana ibadah (zakat dan shodaqoh).

LAGZIS Masjid Al Falah dapat digambarkan sebagai wadah untuk mengumpulkan yang bersumber dari potensi masyarakat, yang kemudian dimanfaatkan dan dikelola sesuai dengan tuntunan syariah, dari, oleh dan untuk masyarakat sendiri dalam rangka meningkatkan taraf kesejahteraan dan memperkuat ekonomi umat. Dengan demikian maka jelas bahwa LAGZIS masjid Al Falah adalah lembaga keuangan berkarakter syariah. Kegiatannya bertujuan pada penguatan dan pengembangan usaha dan membantu masyarakat dalam rangka meningkatkan kesejahteraan sosial dan mempertahakan kehidupan di tengah situasi yang sulit. Namun demikian, lembaga ini bukanlah semata-mata lembaga sosial saja, tetapi juga lembaga ekonomi yang dirancang untuk mencari profit melalui cara-cara yang tidak bertentangan dengan syariah Islam.

Adapun ciri khas yang diterapkan di LAGZIS masjid Al Falah adalah visi dan 
misinya bersifat sosial (non komersial), berfungsi sebagai mediator antara muzakki dan mustahik zakat, antara dermawan dengan masyarakat penerima shodaqoh, dan pembiayaan operasional diambil dari total ZIS sebesar kurang lebih 2,5\% untuk para pelaksana lapangan agar mereka lebih termotivasi untuk melaksanakan tugas, meskipun pada kenyataannya banyak diantara mereka yang tidak bersedia menerima karena merasa itu bagian dari ibadah yang bisa mereka lakukan. Pertimbangan diberikannya upah (ujroh) in adalah karena mereka setiap kamis dan jumat pagi berkeiling mengambil shodaqoh dari masyarakat yang ada di komplek perumahan. Mereka berjalan dari rumah ke rumah sesuai dengan daftar donatur yang sudah terdata di list grop whatsap (WA) dan tidak jarang ketika mereka keliling ada masyarakat yang memberikan shodaqoh secara aepontanitas dan kemudian menjadi donatur tetap.

LAGZIS memadukan aspek ekonomi, aspek sosial, dan aspek keagamaan secara sekaligus. Bereda dengan sistem koperasi umumnya yang hanya terpaku pada unsur ekonomi dan unsur sosial. Aspek sosial maksudnya adalah melayani masayarakat yang sifatnya kreativ, pertolongan, dan pemberdayaan. Aspek ekonomi maksudnya adalah memberdayakan dan mengembangkan ekonomi masyarakat yang sifatnya gurem menjadi komersial. Aspek agama maksudnya adalah LAGZIS sebagai wahana penerapan prinsip-prinsip syariah.

\section{LAGZIS dan Peningkatan Fungsi Masjid}

Masjid pada era Rasulullah menjadi pusat aktivitas umat. Dimana masjid pada saat itu berfungsi sebagai sumber peradaban, tempat menyusun strategi perang, politik, pendidikan, bisnis, seni, termasuk masalah-masalah sosial dibicarakan dan dicarikan solusinya dari dalam masjid.

Said Tuhuleley (2002) mendiskripsikan bahwa paling tidak masjid memiliki dua misi. Misi pertama, sebagai wahana pembersihan diri, dimana masjid sebagai pusat ibadah memfasilitasi setiap muslim untuk selalu menjalankan perintah Allah dan menjauhi larangan-Nya. Misi kedua, adalah pembebasan dan pemberdayan, dimana masjid bertugas untuk mewujudkan manusia yag tidak diperbudak oleh sesamanya dan oleh makhluk-makhluk lainnya. Masjid sebagai pusat aktivitas yang demikian, tidak lagi dijumpai pada zaman sekarang. Bahkan masjid kini difahami sebagai tempat ibadah an sich.

Setelah hijrah ke Madinah kegiatan pertama dari gerakan Nabi adalah mendirikan masjid. Nabi bersama para sahabat bergotong royong membangun masjid, selain berfungsi sebagai tempat ibadah, masjid juga difungsikan untuk beberapa tujuan lain, seperti: tempat pertemuan parlemen (Dewan Perwakilan Rakyat), kesekertariatan mahkamah agung, markas besar tentara, kantor urusan luar negeri, rumah bagi para tamu, pusat pendidikan, tempat pelatihan bagi para penyebar luas agama (seperti pondok pesantren), asrama, baitul maal, tempat para 
dewan, dan utusan. Singkatnya, pada waktu itu masjid sebagai Islamic Centre.

Lembaga keuangan dalam bentuk Baitul Maal Wa Tamwil (BMT) menjadi lembaga keuangan umat yang sudah ada pada masa Rasulullah saw (1-11 H/622$632 \mathrm{M}$ ). Ketika kaum muslimin mendapatkan ghanimah (harta rampasan perang) pada Perang Badar. Saat itu para shahabat berselisih paham mengenai cara pembagian ghanimah tersebut sehingga turun firman Allah swt dalam Al-Qur'an surat Al-Anfal ayat 1:

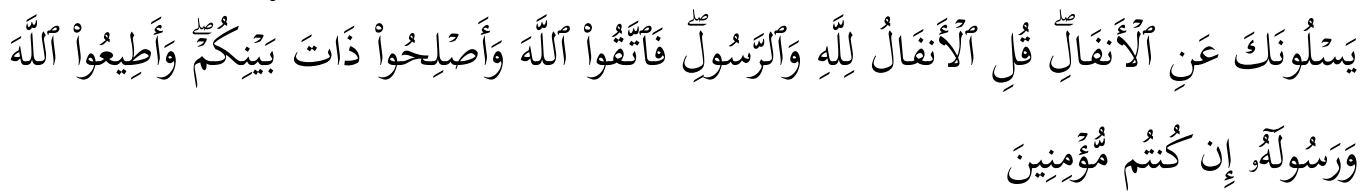

Mereka bertanya kepadamu (Muhammad) tentang (pembagian) harta rampasan perang. Katakanlah, Harta rampasan perang itu adalah milik Allah dan Rasul, oleh sebab itu bertaqwalah kepada Allah dan perbaikilah hubungan di antara sesama kalian, dan taatlah kepada Allah dan Rasul-Nya jika kalian benar-benar orang-orang yang beriman. '(QS. al Anfal (8):1)

Dalam ayat tersebut, Allah menjelaskan hukum pembagian harta rampasan perang dan menetapkannya sebagai hak bagi seluruh kaum muslimin. Selain itu, Allah juga memberikan wewenang kepada Rasulullah saw untuk membagikannya sesuai pertimbangan beliau mengenai kemaslahatan kaum muslimin. Dengan demikian, ghanimah perang Badar ini menjadi hak bagi Baitul Mal, di mana pengelolaannya dilakukan oleh waly al-amr kaum muslimin yang pada saat itu adalah Rasulullah saw sendiri sesuai dengan pendapatnya untuk merealisasikan kemaslahatan kaum muslimin.

Awalnya, Baitul Mal lebih diartikan sebagai pihak (al-jihah) yang menangani setiap harta benda kaum muslimin, baik berupa pendapatan maupun pengeluaran. Saat itu Baitul Mal belum mempunyai tempat khusus untuk menyimpan harta, karena saat itu harta yang diperoleh belum begitu banyak. Kalaupun ada, harta yang diperoleh hampir selalu habis dibagi-bagikan kepada kaum muslimin serta dibelanjakan untuk pemeliharaan urusan mereka. Rasulullah SAW senantiasa membagikan ghanimah dan seperlima bagian darinya (al-khumus) setelah usainya peperangan, tanpa menunda-nundanya lagi. Beliau segera menyerahkan dan menunaikan pembagaian sesuai proporsinya masing-masing. Dengan kata lain, bila harta itu datang pagi-pagi, akan segera dibagi sebelum tengah hari tiba. Demikian juga jika harta itu datang siang hari, akan segera dibagi sebelum malam hari tiba. Oleh karena itu, saat itu belum ada atau belum banyak harta tersimpan yang mengharuskan adanya tempat atau arsip tertentu bagi pengelolaannya ${ }^{9}$

Pada masa Khalafa' Rasyidin, khususnya pada masa khalifah Abu Bakr al-

${ }^{9}$ Sudarsono. 2004. Konsep Ekonomi Islam. Jakarta: Mandar Maju. h. 128. 
Shiddiq (11-13 H/632-634 M), keadaan seperti di atas terus berlangsung sebagaimana masa Rasulullah saw. Ketika Abu Bakr menjadi khalifah, keadaan Baitul Mal masih berlangsung seperti itu di tahun pertama kekhilafahannya (11 H/632 M). Jika datang harta kepadanya dari wilayah-wilayah kekuasaan khilafah islamiyyah, Abu Bakr membawa harta itu ke masjid Nabawi dan membagibagikannya kepada orang-orang yang berhak menerimanya.

Untuk urusan ini, khalifah Abu Bakr telah mewakilkan kepada Abu Ubaidah ibn al-Jarrah. Kemudian pada tahun kedua kekhilafahannya (12 H/633 M), Abu Bakar merintis embrio Baitul Mal dalam arti yang lebih luas. Baitul Mal bukan sekedar berarti pihak (al-jihah) yang menangani harta umat, namun juga berarti suatu tempat (al-makaan) untuk menyimpan harta negara. Abu Bakr menyiapkan tempat khusus di rumahnya berupa karung atau kantung (ghiraarah) untuk menyimpan harta yang dikirimkan ke Madinah. Hal ini berlangsung sampai kewafatan beliau pada tahun $13 \mathrm{H} / 634 \mathrm{M}$.

Abu Bakr dikenal sebagai khalifah yang sangat wara' (hati-hati) dalam masalah harta. Bahkan pada hari kedua setelah beliau dibaiat sebagai khalifah, beliau tetap berdagang dan tidak mau mengambil harta umat dari Baitul Mal untuk keperluan diri dan keluarganya. Diriwayatkan oleh lbn Sa'ad (w. 230 H/844 M), penulis biografi para tokoh muslim, bahwa Abu Bakr yang sebelumnya berprofesi sebagai pedagang membawa barang-barang dagangannya yang berupa bahan pakaian di pundaknya dan pergi ke pasar untuk menjualnya. Di tengah jalan, ia bertemu dengan 'Umar ibn al-Khattab. 'Umar bertanya, "Anda mau kemana, hai khalifah?” Abu Bakr menjawab, "Ke pasar.” 'Umar berkata, "Bagaimana mungkin anda melakukannya, padahal anda telah memegang jabatan sebagai pemimpin kaum muslimin?" Abu Bakr menjawab, "Lalu dari mana aku akan memberikan nafkah untuk keluargaku?" 'Umar berkata, "Pergilah kepada Abu 'Ubaidah (pengelola Baitul Mal), agar ia menetapkan sesuatu untukmu." Keduanya pun pergi menemui Abu 'Ubaidah, yang segera menetapkan santunan (taawiz) yang cukup untuk khalifah Abu Bakr, sesuai dengan kebutuhan seseorang secara sederhana, yakni 4000 dirham setahun yang diambil dari Baitul Mal.

Menjelang ajalnya tiba, karena khawatir terhadap santunan yang diterimanya dari Baitul Mal, Abu Bakr berpesan kepada keluarganya untuk mengembalikan santunan yang pernah diterimanya dari Baitul Mal sejumlah 8000 dirham. Ketika keluarga Abu Bakr mengembalikan uang tersebut setelah beliau meninggal, 'Umar berkomentar, "Semoga Allah merahmati Abu Bakr. Ia telah benar-benar membuat payah orang-orang yang datang setelahnya." Artinya, sikap Abu Bakr yang mengembalikan uang tersebut merupakan sikap yang berat untuk diikuti dan dilaksanakan oleh para khalifah generasi sesudahnya.

Sementara pada masa khalifah 'Umar ibn al-Khattab (13-23 H/634-644 M), setelah masa khalifah Abu Bakr wafat dan 'Umar ibn al-Khattab menjadi khalifah, 
beliau mengumpulkan para bendaharawan kemudian masuk ke rumah Abu Bakr dan membuka Baitul Mal. Ternyata 'Umar hanya mendapatkan satu dinar saja, yang terjatuh dari kantungnya.

Akan tetapi setelah penaklukan (futuhat) terhadap negara lain semakin banyak terjadi pada masa 'Umar dan kaum muslimin berhasil menaklukan negeri Kisra (Persia) dan Qaishar (Romawi), semakin banyaklah harta yang mengalir ke kota Madinah. Oleh karena itu, 'Umar lalu membangun sebuah rumah khusus untuk menyimpan harta, membentuk diwan-diwannya (kantor-kantornya), mengangkat para penulisnya, menetapkan gaji-gaji dari harta Baitul Mal, serta membangun angkatan perang. Kadang ia menyimpan seperlima bagian dari harta ghanimah di masjid dan segera membagi-bagikannya.

Selama memerintah, 'Umar ibn al-Khattab tetap memelihara Baitul Mal secara hati-hati, menerima pemasukan dan sesuatu yang halal sesuai dengan aturan syariat dan mendistribusikannya kepada yang berhak menerimanya. Demikian berikutnya berjalan terus dalam tradisi Islam pasca 'Umar sampai khilafah Utsmaniyyah.

Namun bagaimanapun, terlepas dari berbagai penyimpangan yang terjadi, Baitul Mal harus diakui telah tampil dalam panggung sejarah Islam sebagai lembaga negara yang banyak berjasa bagi perkembangan peradaban Islam dan penciptaan kesejahteraan bagi kaum muslimin. Keberadaannya telah menghiasi lembaran sejarah Islam dan terus berlangsung hingga runtuhnya khilafah yang terakhir, yaitu khilafah Utsmaniyyah di Turki tahun 1924.

Sementara itu di Indonesia, yang mayoritas penduduknya beragama Islam, ada kerinduan terhadap munculnya kembali lembaga keuangan pada awal Islam. Hal ini di samping semangat keberagamaan yang semakin meningkat, juga didorong dengan gagalnya lembaga-lembaga ekonomi yang ada dalam meningkatkan produktifitas dan kegiatan ekonomi yang ada pada era pasar bebas. Akhirnya, saat ini di seluruh Indonesia telah berdiri Baitul Maal Wa Tamwil (BMT) dan Lembaga Amil Zakat, Infaq, dan Shodaqoh (LGZIS). Secara konsepsi BMT dan LAGZIS adalah suatu lembaga keuangan yang di dalamnya mencakup dua jenis kegiatan sekaligus, yaitu:

1 Kegiatan mengumpulkan dana dari berbagai sumber seperti zakat, infaq dan sedekah, dan lain-lain yang dapat dibagikan/disalurkan kepada yang berhak dalam mengatasi kemiskinan.

2 Kegiatan produktif dalam rangka menciptakan nilai tambah baru dan mendorong pertumbuhan ekonomi yang bersumber dari manusia.

BMT dan LAGZIS direkayasa menjadi lembaga solidaritas sekaligus lembaga ekonomi rakyat kecil untuk bersaing di pasar bebas. BMT dan LAGZIS berupaya menjadi jawaban terhadap problematika keuangan dan kemiskinan. Isu kesejahteraan dan pemberdayaan ekonomi umat adalah hal yang menjadi tujuan dimunculkannya BMT dan LAGZIS pada era modern ini. Ada banyak 
penghimpunan dan penyaluran dana yang secara teknis finansial dapat dikembangkan sebuah lembaga keuangan Islam termasuk BMT dan LAGZIS. Hal ini dimungkinkan karena sistem syariah memberi ruang yang cukup untuk itu.

\section{Kesimpulan}

Dari uraian di atas dapat disimpulkan bahwa; peran masjid dalam pemberdayaan ekonomi jama'ahnya telah ada contohnya dalam sejarah dan tradisi umat Islam sejak zaman Rasulullah SAW dan sahabat, yaitu dengan dibentuknya Baitul Maal wat Tamwil (BMT). Saat ini lembaga penguatan ekonomi masyarakat dibutuhkan kehadiarannya di tengah pandemic covid-19. Dibentuknya LAGZIS sebagai representasi lembaga keuangan syariah yang membantu ekonomi jamaah dan masyarakat secara luas menjadi salah satu jawaban masjid terhadap kebutuhan masyarakat.

Namun demikian, kondisi riil fungsi masjid saat sekarang ini masih jauh dari contoh zaman Nabi. Kondisi riil ini diperparah dengan persepsi sebagian masyarakat yang belum bisa menerima pemfungsian masjid dalam banyak aspek kehidupan termasuk pemberdayaan ekonomi masyarakat dan jama'ahnya. Meskipun demikian, pemberdayaan ekonomi masyarakat berbasis masjid memiliki prospek yang cukup cerah karena didukung oleh kondisi masyarakat yang terus mengalami transformasi kearah modernitas. Tinggal bagaimana menyiapkan tenaga dibidang manajemen yang ahli, jujur, dan ikhlas.

Berbagai upaya pemberdayaan dalam kehidupan sosial bermasyarakat memiliki kendala yang berbeda-beda, namun bisa jadi kita dapatkan kendala yang sama. Setiap upaya pemberdayaan yang dilakukan akan berjalan dengan baik jika ada kerjasama yang optimal dari semua pihak yang terlibat. Banyak faktor yang menyebabkan suatu upaya pemberdayaan dapat berjalan dengan maksimal atau tidak diantaranya adalah: ketersediaan dana, keterlibatan secara aktif para partisipan, adanya penggerak yang progresif, dan semua unsur yang dibutuhkan dalam tindakan pemberdayaan tersebut dapat saling bekerjsama dengan baik.

\section{Daftar Pustaka}

Abdurrahman, Moeslim. 1995. Islam Transformatif, Jakarta: Pustaka Firdaus.

Al-Ashari, M. Mufid, 2001. Manajemen Dana dan Pembiayaan Baitul Maal Wat Tamwil. Makalah penelitian BMT. Yogyakarta: LPM UII.

An- Nabahan,M. Faruq. 2000. Sistem Ekonomi Islam. Yogyakarta: UII Press. Baswir, Revrisond. 1997. Agenda Ekonomi Kerakyatan, Yogyakarta: IDEA. Chamsyah, Bachtiar, 2003, Dimensi Religi dalam Kesejahteraan Sosial. Jakarta: Depsos RI.

Departemen Agama RI. 1990. Al-Qur'an dan Terjemahnya, Jakarta: Lembaga Penerjemah Al-Qur'an. 
Djunaidi, Achmad dan Thobieb Al-Asyhar. 2006. Menuju Era Wakaf Produktif: Sebuah Upaya Progresif untuk Kesejahteraan Umat, Jakarta, Mitra Abadi Press.

Dawud, Mochammad. Menerapkan Manajemen Strategi Penyiaran untuk Penyiaran Dakwah. Jurnal Al-Hikmah, 2019, 17.1: 109-140.

Elanda, Yelly. Komodifikasi Agama pada Perumahan Syariah di Surabaya. Jurnal Al-Hikmah, 2019, 17.1: 41-62.

Haroen, Nasrun. 2007. Fiqh Muamalah, Jakarta: Gaya Media Pratama.

Hadi, H. Sofyan. Manajemen Strategi Dakwah di Era Kontemporer. Jurnal AlHikmah, 2019, 17.1: 79-90.

Isfironi, Mohammad. Kota Santri, Bumi Shalawat Nariyah dan Bule-Dhika. Jurnal Al-Hikmah, 2019, 17.1: 1-20.

Ilmi, Makhalul, SM. 2002. Teori dan praktek Lembaga Mikro Keuangan Syariah. Yogyakarta: UII Press.

Jannah, Hasanatul. Pondok Pesantren Sebagai Pusat Otoritas Ulama Madura. Jurnal Al-Hikmah, 2019, 17.1: 91-108.

Lubis, Suhrawardi K. 2000. Hukum Ekonomi Islam. Jakarta: Sinar Grafika.

Mannan, M. Abdul. 1997. Teori dan Praktek Ekonomi Islam. Yogyakarta: Dana Bhakti Wakaf.

Mas'udi, Masdar F. 1991. Agama Keadilan: Risalah Zakat (Pajak) dalam Islam, Jakarta: Pustaka Firdaus.

2006. Memakmurkan Masjid Nahdliyin untuk Kejayaan Umat dan Bangsa, Jakarta: P3M.

Muhammad. 2002. Strategi Pengembangan Lembaga Keuangan Mikro. Makalah seminar Lembaga Keuangan Syariah bagi Nasabah dan Manajer BMT, dalam rangka Dies Natalis UII ke-59, pada tanggal 29 September 2002. Kampus terpadu UII.

---------. 1989. Manajemen Baitul Maal Wa Tamwil (BMT). Yogyakarta: STIS.

---------. 2000. Lembaga-lembaga keuangan umat kontemporer. Yogyakarta: UII Press.

2001. Teknik Perhitungan Bagi Hasil di Bank Syari'ah, Yogyakarta: UII Press.

Nejatullah Shiddiq, Muhammad. 2001. Sejarah pemikiran Ekonomi Islam. Jakarta: PT. Pustaka Pelajar.

Rahman, Afzalur. 1995. Doktrin Ekonomi Islam, Yogyakarta: Dana Bhakti Wakaf.

Suardiman, Siti Partini, 1997. Studi Kasus dalam Studi Gender. Makalah: tidak diterbitkan. Yogyakarta: PSW IKIP Yogyakarta.

Sudarsono, Heri. 2004. Konsep Ekonomi Islam: Suatu Pengantar, Yogyakarta: Ekonisia FE UII.

Syafi'I Antonio, Muhammad. 2001. Bank Syariah dari Teori ke Praktik. Jakarta: 
Al-Hikmah. Vol, 18 No. 1 April 2020

Gema Insani Press.

Syarifudin, Efi. Membangun kemandirian ekonomi Masjid, makalah workshop pemberdayaan ekonomi masjid di Masjid Nurul Iman (24 Desember 2012)

Tim Menejemen BMT. 1995. Konsep Dasar Baitul Maal Wat Tamwil. Yogyakarta: LPM UII-PKPEK.

Wazis, Kun. Perlawanan Ahli Hadis terhadap Gerakan Radikalisme Dalam Konstruksi Media Online. Jurnal Al-Hikmah, 2019, 17.1: 20-40. 